Eva Baaren

\title{
TUSSEN DROOM EN DAAD
}

\section{DE INSTITUTIONELE ONTWIKKELING VAN INTERACTIEVE TELEVISIE IN NEDERLAND EN VlaANDEREN}

$\mathrm{Na}$ vijftig jaar van relatieve stabiliteit is de televisie sinds begin deze eeuw in roerig vaarwater gekomen. Digitalisering en een voortgaande trend van mediaconvergentie hebben er onder andere voor gezorgd dat een oude visie weer tot leven is gewekt, namelijk die van interactieve televisie. Vandaag de dag wordt de term 'interactieve televisie' regelmatig gebruikt door nieuwe partijen die televisie op het internet aanbieden, maar ook door gevestigde partijen in de traditionele televisieketen, als verzamelnaam voor nieuwe digitale televisiediensten en programmaformats. ${ }^{\mathrm{I}}$ Het huidige aanbod van digitale interactieve televisie is echter niet eenduidig, maar kent varianten die in meer of mindere mate verschillen van het traditionele televisieaanbod. Ook blijken er op internationaal niveau verschillen te bestaan. Zo wordt in Nederland de term 'interactief' slechts gebruikt door kabeldistributeurs om video-on-demand toepassingen (het op elk gewild tijdstip kunnen opvragen van films of televisieprogramma's) te verkopen, terwijl men in Vlaanderen en het Verenigd Koninkrijk onder dezelfde noemer ook nieuwe programmaformats en één-op-één communicatiemogelijkheden aanbiedt.

Dit artikel richt zich op de vraag welke dynamieken de ontwikkeling van interactieve televisie door de gevestigde televisieketen in een land bepalen. Hierbij wordt gebruik gemaakt van de sociaalconstructivistische actor-network benadering. De ontwikkeling en het gebruik van een nieuwe technologie wordt volgens deze benadering niet alleen bepaald door de technologie zelf, maar door een constellatie van menselijke actoren en contextuele factoren, die elkaar en het eindproduct beïnvloeden. ${ }^{2}$ Een case study van twee testprojecten voor interactieve televisie uit de recente geschiedenis van Nederland en Vlaanderen geeft antwoord op de vraag op welke manier verschillende actoren en factoren van invloed zijn (geweest) op de ontwikkeling van interactieve televisie. Deze pilotprojecten, genaamd Nederland-i en Vlaanderen Interactief, werden gehouden tussen 2000 en 2005 en dienden als opstap naar een structurele ontwikkeling en uitrol van digitale interactieve televisie. De interactieve toepassingen die uit de projecten voortkwamen, verschilden echter sterk van elkaar, evenals het succes van deze toepassingen na afloop van de projecten. Een vergelijking 
tussen de keuzen van actoren die binnen verschillende nationale, politieke, organisatorische, sociaal-culturele, technologische en economische contexten aan de projecten deelnamen, geeft inzicht in de samenwerkingsprocessen die hebben gezorgd voor verschillen in interactieve platformen, programma's en diensten. Het begrip interactieve televisie wordt hierbij niet van tevoren gedefinieerd. In plaats daarvan wordt interactieve televisie beschouwd als een fenomeen in ontwikkeling waaraan de betekenis juist door de partijen in de keten wordt gegeven. ${ }^{3}$

Niet alleen kunnen door deze analyse de verschillen in het huidige interactieve televisieaanbod tussen Nederland en Vlaanderen beter begrepen worden, ook geeft een dergelijke case study inzicht in de fundamentele mediahistorische vraag welke processen de ontwikkeling van nieuwe mediatechnologieën en -toepassingen in het algemeen bepalen.

\section{Nederland-i en de voortrekkersrol van de Publieke Omroep}

Bij een bestaand medium dat zich in een technologische transitiefase bevindt, zijn het de gevestigde partijen die - vanuit technologische mogelijkheid en een 'idee' van wat het medium in de toekomst kan of moet zijn - het eerst aan zet zijn om deze technologie vorm te geven. Terwijl een nieuwe technologie door één partij gezien wordt als een mogelijkheid de positie in de markt of samenleving te versterken, kan een andere partij deze zien als een bedreiging voor het eigen bestaan. Een technologie wordt daarom altijd aangewend, ontwikkeld en/of gepromoot ter behoud of versterking van de eigen machtspositie. ${ }^{4}$ Voor de Nederlandse Publieke Omroep, die in 200 het pilotproject Nederland-i initieerde, diende de ontwikkeling van interactieve televisie tot behoud van de rol die de Nederlandse Publieke Omroep (N PO) had om de Nederlandse burger in een digitaal medialandschap zo goed mogelijk te blijven bereiken. Deze rol werd, voorafgaande aan het project, door de toenmalige staatssecretaris van Onderwijs, Cultuur en Wetenschap (oc\&w) aan de orde gesteld. 5 Digitalisering zou volgens de staatssecretaris ruimte creëren voor een wildgroei van televisiezenders en andere (hybride) mediavormen. De omroep moest zich daarom voorbereiden op nieuwe manieren om de burger te blijven bereiken. Een van de manieren waarop dit zou kunnen gebeuren was door te anticiperen op 'personalisering' van digitale media. ${ }^{6}$ De staatssecretaris zag interactieve televisie als een van de mogelijkheden voor deze personalisering.

Naast behoud van het publiek van de NPO in een nieuw medialandschap, zou de ontwikkeling van interactieve televisie volgens de staatssecretaris tevens een stimulans kunnen zijn voor de ontwikkeling van landelijke digitale televisienetwerken.7 Vanuit de N Po werd deze mening gedeeld. Uit een verslag van de Expertmeeting Interactieve Televisie die als doel had om tussen omroepen en distributeurs informatie uit te wisselen over ontwikkelingen in digitale tele- 
visie, blijkt dat een uitrol van digitale televisie door middel van vrije marktwerking op korte termijn niet verwacht werd. ${ }^{8}$ Deze impasse werd volgens de leden van de Expertmeeting veroorzaakt door een hoge kabeldichtheid, een goed televisiesignaal en het hoge percentage van burgers die toegang hadden tot het internet. Er zou dus voor de gebruiker geen overtuigende reden zijn om over te stappen naar digitale televisie. Ook zou de Nederlandse kijker geen hoger bedrag willen betalen voor een overstap naar digitale televisie, omdat deze de televisie zou zien als een nutsvoorziening, waar niet of nauwelijks voor betaald hoefde te worden. Als gevolg hiervan bleven investeringen in digitale televisie door omroepen en distributeurs uit, terwijl in het buitenland (voornamelijk bij de Britse BBC en de Duitse publieke omroepen ARD en ZDF) al werd geëxperimenteerd met interactieve televisie. De n po had de mogelijkheid om van overheidsgelden gebruik te maken en wilde, onder voorwaarde van aanvullende subsidie, daarom de taak op zich nemen de impasse te doorbreken door een aantrekkelijke digitale inhoud te bieden. ${ }^{9}$ Deze subsidievoorwaarde werd gehonoreerd door middel van een overheidsbijdrage op de lange termijn: de omroepbijdrage zou jaarlijks met I, $5 \%$ verhoogd worden en vanaf 2003 naast internetactiviteiten ook besteed worden aan interactieve televisie. ${ }^{\mathrm{I}}{ }^{\circ} \mathrm{In} 200 \mathrm{I}$ en 2002, tijdens het pilotproject, zou de Publieke Omroep een beroep doen op het eigen Fonds Omroepreserve, waarin I3,5 miljoen gulden (ca. 6,I miljoen euro) werd begroot voor de technische en inhoudelijke realisatie van interactieve televisie.

Binnen de kabelsector was het toenmalige kabelgenootschap Mediakabel, bestaande uit een aantal grote kabelmaatschappijen waaronder Eneco en UPC, de voor de hand liggende partij om met de NPO samen te werken. In tegenstelling tot andere kabelbedrijven had Mediakabel al de eerste stap richting digitalisering gezet in een eigen testproject genaamd MR. ZAP. Abonnees van Mediakabel werd een basispakket van themakanalen, radiozenders, een elektronische programmagids (EPG) en simpele computergames aangeboden. Ook konden er films worden bekeken via het near-video-on-demand principe, waarbij er op parallelle kanalen om de zoveel tijd een aantal films werden uitgezonden waar de gebruiker uit kon kiezen. Bijgeleverd werd een 'set-topbox', oftwel een digitale decoder, welke aangesloten moest worden op het televisietoestel. Deze

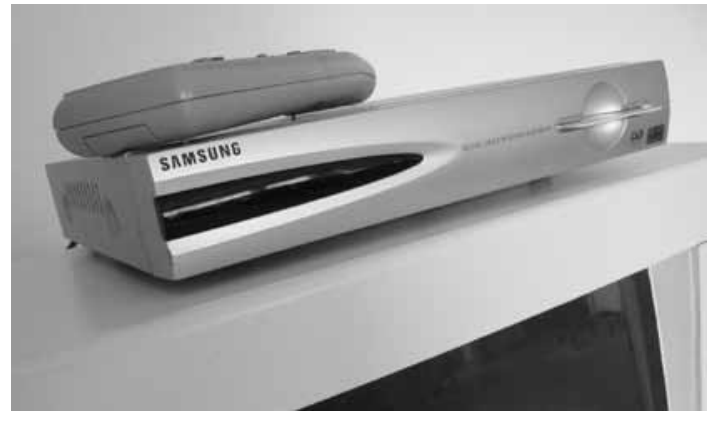

Voorbeeld van een set-topbox.

Bron: foto auteur 
set-topbox maakte gebruik van relatief goedkope en ver ontwikkelde 'OPEN-TV' middleware, dat zorgde voor de technische realisatie van interactieve toepassingen. De services van MR. ZAP waren echter niet genoeg om de verwachte groei van abonnees te halen. Met de interactieve programma's en diensten die de NPO zou gaan ontwikkelen, hoopte Mediakabel het aantal abonnees weer te doen toenemen. ${ }^{\text {II }}$

\section{Van concepten naar uitvoering: een waaier van programma's}

Voor het project Nederland-i had de Nederlandse Omroep Stichting (Nos), een projectomschrijving opgesteld. Per zender, en daarbinnen per omroep, zou een coördinator worden aangewezen, die de plannen van de omroep en de aanvragen voor de daarvoor benodigde technische faciliteiten terugkoppelde naar de Nos. ${ }^{12}$ De eisen die er op technisch en inhoudelijk gebied gesteld werden, waren echter zeer ruim. Voorbeelden van interactiviteit die in de omschrijving werden genoemd varieerden van 'keuzetelevisie' (het kiezen tussen scenario's en schakelen tussen camerastandpunten), het opvragen van extra informatie, uitgesteld kijken, pay-per-view televisie, responstelevisie (reageren op de inhoud) tot 'homeshopping'. ${ }^{13}$ Wel hadden 'voorstellen waarin de kijker de gelegenheid wordt geboden het verloop van het programma samen te stellen (...) de voorkeur'. ${ }^{14}$ Ook werden toepassingen die gebruik zouden maken van een retourpad, waarbij de kijker een signaal terug kan zenden naar de omroep, gezien als 'interactiever' vergeleken met toepassingen waarbij dit niet het geval was. ${ }^{15}$ Andere mogelijkheden werden echter niet uitgesloten, dus bleef het aan de individuele omroepen om, binnen de grenzen van de opgelegde techniek (OPEN-TV technologie en een retourpad via kabel of via andere media, zoals telefoon en internet) interactieve televisievormen te ontwikkelen.

De nos heeft haar projectomschrijving breed gehouden en heeft de omroepen daarmee veel vrijheid gegeven in het bepalen van interactieve programma's en diensten. Dit heeft te maken met de organisatiestructuur van de NPO want deze is, als overblijfsel van de verzuiling, tot op heden zeer gefragmenteerd. Volgens de toenmalige coördinator van het project was het vanwege deze organisatorische situatie niet verstandig om strak omlijnde regels te geven: 'Omroepen hebben een sterke eigen identiteit en zullen alleen maar met iTv gaan experimenteren als ze de vrijheid hebben dit naar eigen inzicht te doen'. ${ }^{16}$ Meer dan een afbakening van interactieve vormen diende de projectomschrijving dus als stimulans voor deelname aan het project.

Als gevolg van de brede projectomschrijving zijn er door verschillende publieke omroepen elf programma's ontwikkeld die van elkaar verschilden in frequentie, gebruiksmogelijkheden en technische uitvoering. Zo brachten de programma's TOP OF THE POPS (BNN, muziek), STAND.NL (NCRV, radio-praatprogramma), HELPDESK LIVE (EO, praatprogramma), DE ONTDEKKING (VARA, 
populair wetenschappelijk) en WALKING WITH BEASTS (door de NCRV aangekocht, populair wetenschappelijk) een vorm van verrijkte televisie, waarbij extra informatie kon worden opgevraagd door op een van de knoppen op de afstandsbediening te drukken. Er verscheen een scherm waarop deze informatie te lezen of, in het geval van audiovisueel materiaal, te bekijken was. ${ }^{17}$ Ook boden een vijftal reclamespotjes van voornamelijk verzekering- en creditcardmaatschappijen de mogelijkheid voor het opvragen van extra informatie. Bij de spelprogramma's zo VADER, Zo ZOON en de NATIONALE NIEUWSQUiZ (NCRV) konden kijkers via de afstands-

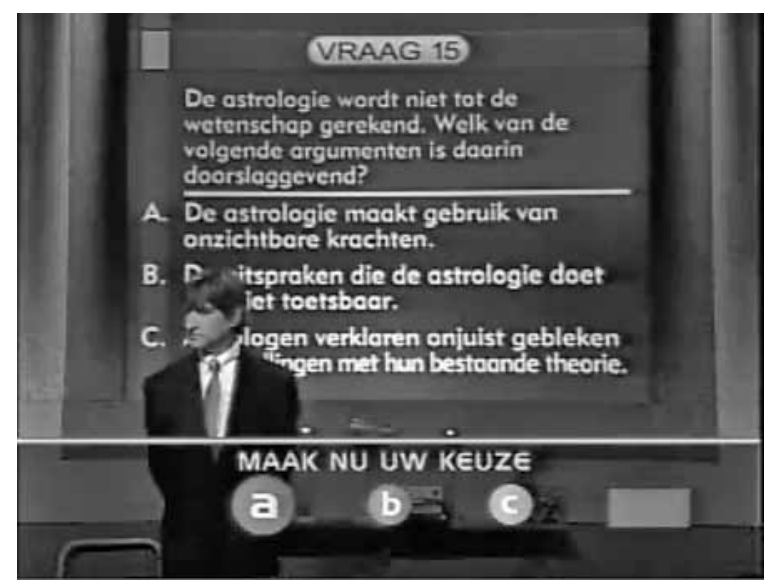

VPRo's NATIONALE WETENSCHAPSQUiz tijdens Nederland-i. Bron: R. van de Paverd, iTv-dossier, NOS DTA, Publieke Omroep, Hilversum, juli 2002 bediening meespelen, maar de gegevens werden niet via een retourpad teruggestuurd. Dit kon echter wel bij de NATIONALE WETENSCHAPSQUIZ (VPRO), waarbij de eigen resultaten konden worden vergeleken met die van andere kijkers. Het programma HELPDESK LIVE gaf de mogelijkheid om te reageren in de uitzending, maar dit verliep via e-mail of telefoon en niet via de kabel. In de programma's STAND.NL, VOOR JE KIEZEN (IKON, spelprogramma) en de GOUDEN LOEKI verkiezing (STER) kon naast het internet, telefoon en sms, wél via de kabel worden gestemd. Het programma DUIVELSE DILEMMA'S (AVRO, spelprogramma) vroeg kijkers voorafgaand aan het programma de antwoorden van andere kandidaten te voorspellen via het internet. Tenslotte werd er door HELPDESK LIVE en STAN D.NL van timeshifting gebruik gemaakt, door afleveringen op aanvraag aan te bieden. Omdat de set-topboxen echter geen harde schijf hadden en de programma's niet van tevoren naar de set-topboxen gezonden konden worden, is het waarschijnlijk dat deze functie bestond uit near-video-on-demand met een aantal vaste momenten waarop de kijker in een uitgezonden herhaling van het programma kon instappen. ${ }^{\text {I8 }}$

Nederland-i bood dus een diversiteit aan toepassingen die verschilden in genre (quizzen, infotainment en praatprogramma's) en retourkanalen (geen, via set-topbox, telefoon, sms of internet). Programmaformats waren daarbij ook niet nieuw. Door middel van informatie op websites en de mogelijkheid tot reacties via internet, telefoon of sms konden kijkers vaak al vóór het project informatie opvragen of reageren. Deze retourkanalen bleven ook tijdens Nederland-i in gebruik. Ook valt op dat er van sommige programma's een heel seizoen interactief werd gemaakt, terwijl er van andere slechts enkele losse afleveren werden geproduceerd. Deze verschillen traden vooral op tussen de omroepen. Volgens de benadering van het actor-centered institutionalism, een benadering die tevens afgeleid is van de actor-network theorie, moet een organisatie niet 
beschouwd worden als een geheel, maar als een 'arena' waarbinnen verschillen actoren met verschillende interesses gezamenlijk de ontwikkeling van een innovatie bepalen. ${ }^{19}$ De keuzen die deze actoren maken, zijn hierbij afhankelijk van de randvoorwaarden die een organisatie aan deze keuzen stelt. ${ }^{20}$ Het gebrek aan centrale sturing vanuit de NPO heeft de ontwikkeling van uiteenlopende interactieve televisieformats in de hand gewerkt. Behalve verschillende interesses hebben ook technische en financiële beperkingen bijgedragen aan de ontwikkeling van de formats. Zo wilden de varA en de NPs een vorm van interactiviteit ontwikkelen waarbij de kijker kon kiezen tussen verschillende camerastandpunten en verhaallijnen. De bandbreedte van de kabel bleek hiervoor echter te laag en de opnamekosten voor verschillende verhaallijnen juist te hoog. ${ }^{2 \mathrm{I}}$ Ook was het budget voor veel omroepen daarbij krapper dan verwacht omdat een groot deel van het voor digitale ontwikkelingen gereserveerde bedrag binnen de NPO uiteindelijk besteed werd aan projecten die zich concentreerden op toepassingen voor het internet. ${ }^{22}$ Naast een gebrek aan centrale sturing binnen de N PO op inhoudelijk niveau, heeft het gebrek aan specifieke voorwaarden voor besteding van het budget dus tevens zijn stempel gedrukt op de vorm van interactieve televisie die uit het project is voortgekomen.

\section{Tegenvallend gebruikersenthousiasme}

De verzameling van interactieve programma's die door de opzet van dit project is ontstaan, had slechts een beperkt draagvlak bij het publiek. Uit het evaluatierapport 'Interactieve tv' dat tegen het einde van het project door de N PO is gepubliceerd wordt duidelijk dat percentages van kijkers die gebruik maakten van de verschillende interactieve toepassingen over het algemeen vrij laag waren (4 tot $8 \%$ ). ${ }^{23}$ De mensen die niet hadden meegespeeld, hadden 'geen interesse' of zeiden niet te weten dat interactief meespelen mogelijk was. ${ }^{24}$ Het gebrek aan interesse is te verklaren door het idee dat Tv kijken een lean back activiteit is, waarbij er geen ruimte is voor interesse in interactiviteit. De belangstelling voor nieuwe interactieve mogelijkheden was volgens het evaluatierapport echter wel degelijk aanwezig. ${ }^{25}$ De oorzaak moet dus tevens worden gezocht in de uitvoering van de interactieve toepassingen. Zo kan een haperende techniek de behoefte aan deelname snel hebben teruggebracht, of bleek het gebruik van de telefoon, sms, internet of de afstandsbediening toch meer moeite dan aanvankelijk werd aangenomen.

Het gebrek aan kennis over de interactieve mogelijkheden van een uitzending is te verklaren door technische problemen en een gebrek aan goede voorlichting aan het testpubliek. Met uitzondering van de NATIO NALE NIEUwSQUIZ en de NATIONALE WETENSCHAPSQUIZ, waren geen van de ontwikkelde programma's grote publiekstrekkers. De meeste programma's werden in de middag of laat op de avond uitgezonden. Daarbij verviel soms de geplande interactiviteit 
ook, omdat de tapes met interactieve metadata - bij gebrek aan een digitale interne infrastructuur - niet altijd op tijd op de goede plaats waren. De metadata konden dus niet altijd worden meegezonden met de uitzending. ${ }^{26}$ De onzekerheid over de werking en het tijdstip van uitzending van de interactieve programma's leidde ertoe dat de NPO aan alle omroepen het advies gaf om de interactieve televisieontwikkeling liever 'low profile' te houden. ${ }^{27}$ Er werd dus vanuit de omroepen weinig aandacht geschonken aan de promotie van de eigen interactieve programma's. Daarnaast deed Mediakabel ook weinig aan promotie. De informatie van het kabelconsortium richtte zich veel meer op de promotie van betaalkanalen ten gunste van de eigen winst, dan op de promotie van de programma's van de NPO. ${ }^{28}$

\section{Na Nederland-i: het einde van de samenwerking}

Hoewel een aantal omroepen na de pilot door is gegaan met het ontwikkelen van interactieve formats, is het project Nederland-i afgerond zonder direct vervolg. De n po was er niet in geslaagd de impasse te doorbreken met de uitrol van interactieve televisie. De interactieve programma's die door de NPo zijn gemaakt bleken, door het gefragmenteerde en voor de kijker onduidelijke aanbod, nauwelijks aan te slaan en boden voor Mediakabel weinig extra houvast om meer klanten te werven. Omdat Mediakabel al langer met MR. ZAP bezig was en zijn verliezen zag groeien, werd kort na afloop van Nederland-i ook het project MR. ZAP beëindigd. Mediakabel verschoof zijn investeringen van digitale televisie naar breedband internet, waarna er voor de N Po geen distributeur meer was om zijn digitale interactieve producties aan door te geven. ${ }^{29} \mathrm{Pas}$ nadat kabelbedrijven de druk van nieuwe concurrenten uit de telecomwereld in de markt voelden en het publiek langzaam op digitale televisieabonnementen begon over te stappen, werd het begrip 'interactieve televisie' door de kabelbedrijven weer opgepikt en gebruikt voor de promotie van abonnementen met elektronische programmagidsen en video-on-demand toepassingen. En hoewel de standaardisering van middleware en vooral van interactieve knoppen op de afstandsbediening sinds 2007 bij omroepen en distributeurs weer hoog op de agenda staan, ${ }^{30}$ zijn zowel de NPO als de commerciële omroepen tot vandaag de dag nog steeds terughoudend in het aanbieden van interactieve programma's via de set-topbox.

\section{Vlaanderen Interactief}

Een jaar na afronding van Nederland-i werd in Vlaanderen eveneens een testproject rondom interactieve televisie opgezet. Bij dit project waren niet alleen de Vlaamse publieke omroep (VRT) en kabeldistributeurs Telenet en Interkabel 
betrokken, maar namen ook twee grote commerciële omroepen, vм мa en vT4, deel..$^{3 \mathrm{~T}}$ Tevens werd het project gesteund door drie ministeries, te weten het ministerie van Financiën en Begroting, Ruimtelijke Ordening, Wetenschappen en Technologische Innovatie, het ministerie van Economie, Buitenlands Beleid en E-government en het ministerie van Wonen, Media en Sport.

Anders dan in Nederland werd het Vlaamse project niet geïnitieerd door de publieke omroep maar door kabeldistributeur Telenet. Telenet wilde, net als het Nederlandse Mediakabel had gedaan met M R. ZAP, oorspronkelijk een geisoleerd testproject starten, maar had niet de financiële middelen dit op eigen kracht te doen..$^{32}$ Omdat Telenet nog gedeeltelijk van een overheidsinfrastructuur gebruik maakte, deed het kabelbedrijf een subsidieaanvraag voor de overstap naar digitale televisie bij het ministerie van Financiën en Begroting, Ruimtelijke Ordening, Wetenschappen en Technologische Innovatie. De minister kende de subsidie toe op de voorwaarde dat Telenet een samenwerkingsverband met de Vlaamse publieke en commerciële omroepen zou aangaan. ${ }^{33}$ Naast de omroepen stapte ook distributeur Interkabel in. Op 3 september 2003 tekenden de publieke en commerciële omroepen, de drie ministeries en distributeurs Telenet en Interkabel een overeenkomst waarin de samenwerking werd vastgelegd. In de overeenkomst stond dat het proefproject zou worden gehouden onder 300 testgezinnen in de omgeving van een viertal middelgrote Vlaamse steden. Verder zou de Vlaamse overheid 50\% van de kosten, die geschat werden op 25 miljoen euro, subsidiëren voor elke deelnemende partij, inclusief de commerciële omroepen. ${ }^{34}$ In januari 2005 is het project beëindigd en geëvalueerd.

\section{Overheidssturing en samenwerking}

Omdat in Vlaanderen de analoge televisie en de Gsm-markt verzadigd waren, was de overstap naar digitale diensten en distributie voor Telenet een mogelijkheid om nieuwe inkomsten te genereren. ${ }^{35}$ Dit was niet alleen mogelijk door het aanbieden van nieuwe abonnementen met betaaldiensten als games, themakanalen en video-on-demand zoals in Nederland was gedaan door Mediakabel. Ook behoorden de ontwikkeling van toepassingen die waren afgeleid van websites op het internet en één-op-één communicatiemogelijkheden tussen televisiekijkers tot de mogelijkheden. In tegenstelling tot in Nederland was de internetpenetratie in Vlaanderen met 35\% zeer laag, en spraken zowel Telenet als de overheid van een binnenlandse 'digitale kloof' ${ }^{36}$ Telenet kon met digitale televisiediensten die afgeleid waren van het internet een groot gat in de markt vullen.

Voor de Vlaamse overheid waren de motieven om het pilotproject te steunen, tweeledig. Net als in Nederland zat Vlaanderen in een impasse wat betreft de overgang naar digitale televisie. De ontwikkeling van digitale interactieve diensten kon ook hier zorgen voor een impuls in de markt. In vergelijking met 
de rest van Europa betekende dat volgens één van de betrokken ministers niet alleen dat Vlaanderen bij zou blijven in nieuwe technologische ontwikkelingen, maar dat het Belgische district zelfs 'Europees koploper' kon worden. ${ }^{37}$ Ervaring met interactieve diensten zou leiden tot een toename van kennis en een stimulans van de Vlaamse economie en werkgelegenheid.

De tweede en tevens prominent genoemde reden was de mogelijkheid om met interactieve televisie de eerdergenoemde digitale kloof te verkleinen. Niet alleen zouden burgers daarmee toegang kunnen krijgen tot commerciële diensten, maar ook zou via interactieve toepassingen de communicatie tussen overheid en burger kunnen worden verbeterd. Het streven naar een verbetering van die communicatie paste binnen de bredere 'eEurope' en 'e-government' projecten, waarbinnen de ontwikkeling en verbetering van overheidsdiensten via ICT centraal stond..$^{8}$ Als gevolg hiervan werd aan het project niet alleen subsidie toegekend, maar profileerde het ministerie van Economie, Buitenlands Beleid en E-government zich ook als één van de partijen die de interactieve televisiediensten zouden gaan ontwikkelen.

In tegenstelling tot Nederland-i, heeft de Vlaamse overheid de toezegging voor subsidie gekoppeld aan de voorwaarde dat Telenet zou samenwerken met de VRT en de commerciële omroepen. Deze beslissing was gebaseerd op de ervaringen uit een eerder testproject van de VRT en telecomaanbieder Belgacom, genaamd 'digitaal thuisplatform'.39 Tijdens dit project werd de afwezigheid van deelname door de commerciële omroepen beschouwd als een grote factor voor het gematigde enthousiasme waarmee interactieve televisie werd ontvangen door zijn testgebruikers, omdat deze gebruikers steeds moesten schakelen tussen de digitale VRT-kanalen en diensten en de nog steeds analoge commerciële kanalen. Een van de aanbevelingen voor verdere ontwikkelingen in het eindrapport van het DTP-project luidt dan ook: 'Conditio sine qua non is dat de belangrijkste Vlaamse omroepen samen een aanbod van digitale interactieve diensten aan de klant/kijker voorstellen.'40

Een tweede reden om alle omroepen te laten participeren in het project van Telenet bleek ook de wens voor standaardisatie van de set-topboxen. Het DTPproject maakte gebruik van andere middleware (XML, HTML en ECMAscript) dan Vlaanderen interactief (Multimedia Home Platform of мнP). Door alle partijen bij het tweede project te betrekken, zou мн р de overheersende standaard kunnen worden. ${ }^{\text {I }}$ Daarbij was de kabel ook de geprefereerde distributeur boven de ether of ADSL vanwege zijn grote bereik: $98 \%$ van de huishoudens had in 2003 kabeltelevisie. ${ }^{2}$

Voor de VRT, die net een dergelijke projecttest achter de rug had, was Vlaanderen Interactief geen 'must', maar deze pilot gaf de omroep wel een nieuwe en goedkope gelegenheid - de Vlaamse overheid betaalde immers de helft van de gemaakte kosten - om de eerder opgedane kennis en ervaring met digitale televisie te gebruiken voor de verdere ontwikkeling van interactieve programma's en diensten. ${ }^{43}$ De commerciële omroepen vммa en vT4 hadden daar- 
entegen nog niet eerder in een dergelijk project geparticipeerd en kregen door de opzet van Vlaanderen Interactief de kans om aan een testproject mee te doen, terwijl de overheid ook voor deze omroepen de helft van de gemaakte kosten zou betalen. Ook hier speelde het behoud van de kijker een belangrijker rol dan enthousiasme voor de nieuwe mogelijkheden van digitale televisie. De komst van digitale televisie was volgens de technisch directeur van de vмма, Jozef Mertens, zelfs een zorgelijke ontwikkeling, omdat de aanwezigheid van set-topboxen met harde schijven het de kijker eenvoudig zou maken om reclames over te slaan. Als gevolg hiervan zouden reclame-inkomsten terug kunnen lopen. ${ }^{44}$ De komst van digitale televisie werd echter ook beschouwd als onvermijdelijk. Vlaanderen Interactief bood een platform om zowel de positieve als negatieve mogelijkheden van digitale televisie te testen.

Voor het kleinere kabelconsortium Interkabel was deelname aan het project ten slotte onvermijdelijk. Tijdens het project was Interkabel bezit van de Vlaamse overheid maar ook aandeelhouder van Telenet. Daarnaast leende het consortium zijn kabelnetwerk aan Telenet voor internet- en telefoniediensten. Het kabelnetwerk van Interkabel zou, met steun van de Vlaamse overheid, gebruikt gaan worden ter realisatie van de pilot door Telenet. Er zouden in dat geval over hetzelfde netwerk tegelijkertijd twee soorten televisie naast elkaar worden geboden, namelijk analoge televisie via Interkabel en digitale televisie via Telenet. Interkabel maakte daarop de keuze om naast Telenet actief te participeren in het project. 45

De brede opzet van Vlaanderen Interactief blijkt vooral te danken aan voorwaarden voor brede samenwerking die de Vlaamse overheid aan de subsidie voor Telenet had gesteld. Deze voorwaardelijke overheidssteun is een gevolg van ervaringen uit een ouder vRT-project maar vooral van de internationale economische doelstellingen en de wens de digitale informatievoorziening voor eigen burgers te verbeteren.

\section{Van concepten naar uitvoering: een waaier van diensten}

De motieven van de verschillende spelers die de overheid bij elkaar heeft gebracht in het Vlaamse project, hebben hun stempel gedrukt op de vormen van interactieve televisie die tijdens dit project zijn ontwikkeld. Net als in Nederland heeft het pilotproject geleid tot een hybride vorm van interactieve televisie. Echter is die vorm van een heel andere aard. In Nederland werd de pilot, naast de elektronische programmagids en de film on-demand diensten van MR. ZAP, vooral gekenmerkt door de interactieve programma's van de NPO. In Vlaanderen speelden de extra diensten buiten de programmering echter een beduidend grotere rol. Telenet bood, net als bij MR. ZAP, films op on-demand basis en een aantal simpele games. Maar anders dan in Nederland bood de distributeur ook een applicatie met de naam 'communicatie' waarbij gebruikers 

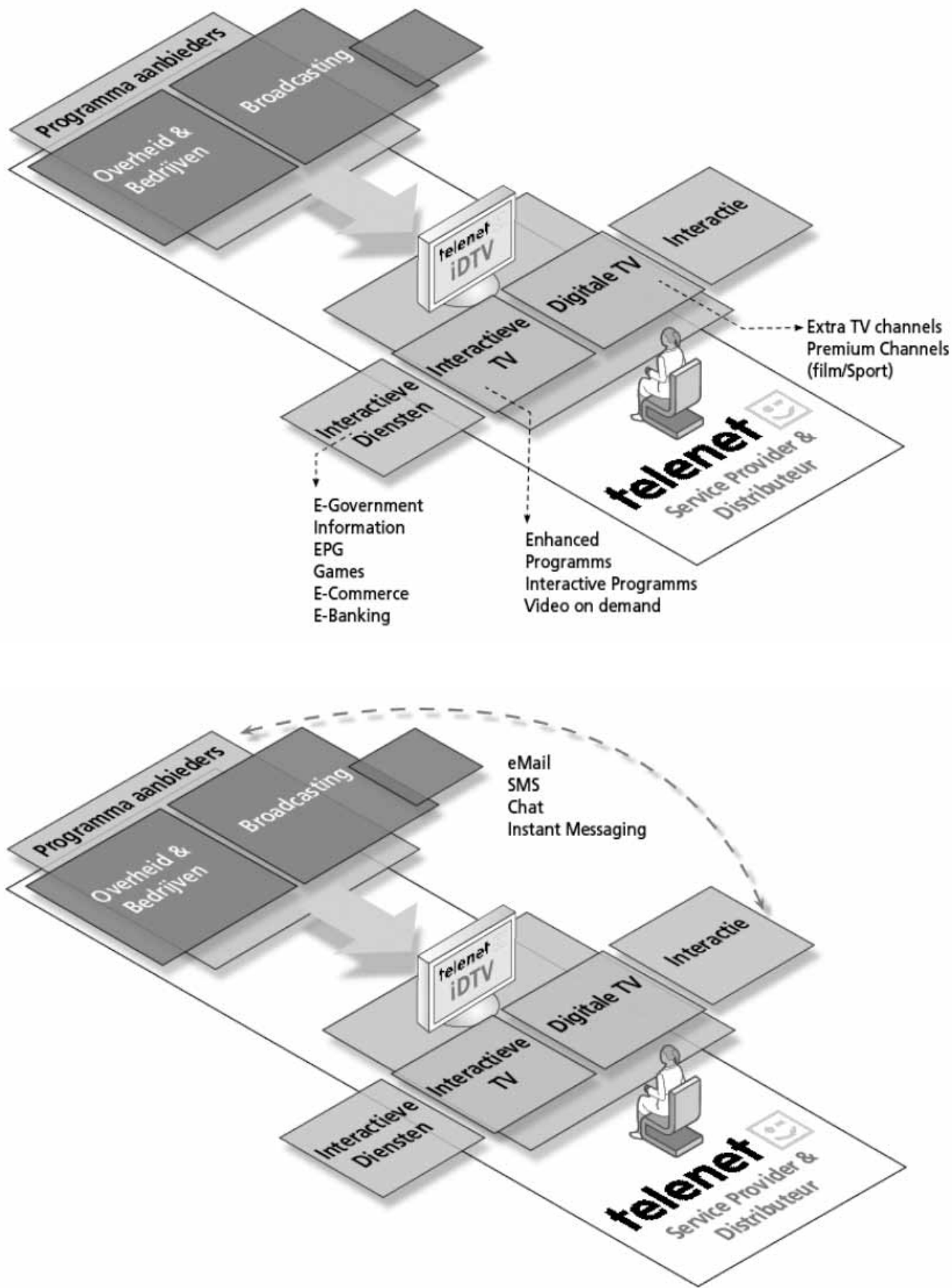

Architectuur van Vlaanderen Inter-actief.

Bron: R. Verhelst, Powerpoint presentatie Telenet. Ge jaarcongres tv en internet, Amsterdam, 25 november 2004, p. 16-17 
door middel van een bijgeleverd toetsenbord met andere televisiekijkers en internet- of mobiele telefoongebruikers konden e-mailen, chatten, en smsen. De anticipatie op het dichten of profiteren van de 'digitale kloof' kan de aanwezigheid van deze diensten verklaren. Ook werden er twee andere, webtv-achtige diensten ontwikkeld die in Nederland-i afwezig bleven. Eén ervan was de webomgeving van de Vlaamse overheid. Hierin konden gebruikers gemeentelijke en landelijke informatie over openingstijden, diensten en procedures opzoeken. Ook konden er vragen worden gesteld door middel van het invullen en terugsturen van een digitaal formulier. Daarnaast bestond er een routeplanner van een Vlaamse openbare vervoersmaatschappij en kon de gebruiker vacatures vinden via het arbeidsbureau. De keuze die gemaakt was voor een set-topbox met open standaard middleware (мнр) zorgde ervoor dat ook derde partijen zoals adverteerders op eenvoudige wijze interactieve toepassingen konden ontwikkelen en aanbieden. Deze toepassingen werden dan ook door ongeveer 15 bedrijven ontwikkeld en bestonden uit extra informatie over producten, prijsvragen, discussiefora en vormen van homeshopping waarbij gebruikers producten daadwerkelijk konden bestellen. ${ }^{6}$ In vergelijking met Nederland-i, waar de gesloten 'OPEN-Tv' standaard was gebruikt en er slechts een viertal adverteerders deelnam, was het aanbod ruim drie keer zo groot. Naast de keuze voor de middleware kan dit verschil ook verklaard worden door het reeds genoemde verschil in internetpenetratie: in Nederland konden producten door veel mensen via internet worden besteld. De verwachtingen van de werking van interactieve televisietoepassingen lagen voor Nederlandse adverteerders wellicht wat lager.

Naast het aanbod van extra diensten door Telenet, de overheid en derde partijen, richtte ook het aanbod van de omroepen zich op andere vormen van interactiveit dan in Nederland het geval was. In vergelijking met de elf interactieve programma's van de NPO, werden er in Vlaanderen slechts zes ontwikkeld. Twee van deze programma's waren van de VRT, twee van vT4 en nog eens twee van vтм. Net als in Nederland bestonden de programmaformats al en werden ze voorzien van een interactieve component. De VRT ontwikkelde interactieve afleveringen van de programma's DOE DE STEMTEST en VLAANDEREN VAKANTIELAND. Doe DE STEMTEST was een spelprogramma gericht op de verkiezingen, dat bestond bij de gratie van interactiviteit. Het publiek kon een aantal vragen in multiple choice beantwoorden en kreeg daarna een berekening van zijn politieke voorkeur. De vragen konden beantwoord worden via de kabel (door middel van de knoppen op de afstandsbediening) of per SMS. VLAANDEREN VAKANTIELAND was een informatief reisprogramma dat werd uitgebreid met de mogelijkheid extra informatie op te vragen. Ook kon de kijker meedoen aan een prijsvraag, waarbij antwoorden via de kabel of telefonisch konden worden doorgeven. VT4 ontwikkelde voor de twee reality programma'S EXPEDITIE ROBINSON En PEKING EXPRESS verrijkte omgevingen, waarbij achtergrondinformatie over de kandidaten en presentatoren kon wor- 
den gevonden en extra filmmateriaal bekeken kon worden. Door de VTM werd het programma idool (de Vlaamse versie van het Britse programmaformat POP IDOL) voor het testproject aangepast. De kijkers konden al telefonisch en per sms stemmen op hun favoriete kandidaten. Tijdens Vlaanderen Interactief konden kijkers dit ook via de kabel doen. Het zesde interactieve programma was het spelprogramma SAVE waarbij kandidaten in de studio multiple choice vragen moesten beantwoorden. Aan het eind van de quiz was er een kijkersvraag die de kijkers behalve telefonisch of per sms nu ook via de kabel konden beantwoorden.

De ontwikkelde interactieve programma's kenmerkten zich door het feit dat, net als in Nederland, geen van de formats zich beperkte tot een retourpad via de kabel. Ook bouwden ze voort op reeds bestaande en soms reeds interactieve programma's. Wel bestonden de Vlaamse formats, met name EXPEDITIE ROBINSON, PEKING EXPRESS en IDOOL, uit grote publiekstrekkers. Verder waren de zes programma's slechts een klein deel van het totaal aan toepassingen dat de omroepen in het project hebben ontwikkeld. Het andere deel bestond uit enkele tientallen programma's die door de VRT, vT4 en de vмма on-demand beschikbaar werden gesteld. Deze lijst van programma's was opgenomen onder de rubriek 'TV op aanvraag', dat naast 'film op aanvraag' bestond binnen het hoofdmenu van Telenet. 47 De verschillen tussen de keuze in populariteit van de interactieve toepassingen en de keuze voor on-demand toepassingen kunnen verklaard worden door een verschil in organisatiestructuur. Terwijl in Nederland de ontwikkeling van interactieve televisieconcepten werd uitbesteed aan de verschillende omroepen en producenten, lag deze ontwikkeling bij de VRT in handen van een klein team. Dit team had de overtuiging dat de televisiekijker een lean-back houding gewend was, en interactiviteit alleen werkte door een selectie van bestaande maar bekende programma's te voorzien van een duidelijke interactieve dimensie..$^{8}$ De centrale organisatiestructuur van de commerciële Vlaamse omroep maakte het ook voor deze omroepen mogelijk de ontwikkeling van de interactieve formats in de handen van een klein team te houden. Ook konden deze teams ervoor kiezen de nadruk niet op de real-time uitgezonden programma's te leggen, maar op het aanbod van programma's on-demand. Volgens de toenmalige coördinator van de pilot bij de VRT zou de controle over de programmering voor de kijker steeds belangrijker worden. Interactieve digitale televisie zou ervoor zorgen dat 'de kijker eindelijk bevrijd is van het klassieke, lineaire televisieschema'.49 In de ontwikkeling van interactieve diensten kon deze visie ook doorgezet worden, omdat er naast een centrale organisatie geen technische bezwaren waren. In de settopbox die voor Vlaanderen Interactief werd gebruikt, zat, in tegenstelling tot die van Nederland-i, een harde schijf. Audiovisueel materiaal kon dus naar de set-topbox gepushed worden en daar op elk tijdstip geraadpleegd worden door de gebruiker. 


\section{Digitale Vrede}

De aanwezigheid van kabelmaatschappijen, omroepen, adverteerders en de overheid in een project heeft zijn stempel gedrukt op de hybride vorm van interactieve televisie die er uit Vlaanderen Interactief is voortgekomen. De omroepen hebben interactieve programmering ontwikkeld en tests gedaan met video-on-demand. Telenet heeft zijn rol van kabeldistributeur zowel als dienstenaanbieder verwezenlijkt en de overheid heeft toepassingen gecreëerd die bedoeld waren om de digitale kloof te dichten. De gekozen middleware met open standaard (МнР) heeft verder bijgedragen aan het feit dat ook partijen buiten de televisieketen diensten konden leveren. De rijkheid aan toepassingen is echter alleen tot stand gekomen vanwege de door de overheid genoemde 'pax digitalis'. ${ }^{\circ}$ Het feit dat alle deelnemende partijen tegelijkertijd een financiële overheidsimpuls kregen ten behoeve van de samenwerking in het project, zorgde ervoor dat alle partijen zich ook tegelijkertijd toelegden op het ontwikkelen en promoten van interactieve toepassingen. Zonder deze overheidsvoorwaarde was Telenet begonnen aan digitalisering van zijn netwerk, maar hadden de omroepen geen reden zich op dat moment bezig te houden met interactieve televisie. De VRT had immers zijn tests al eerder gedaan en de commerciële omroepen waren eerder bang dan gelukkig met de overstap op digitale televisie. Hoewel er voor dit onderzoek geen bewijs is dat de M HP-standaard tevens door de overheid als harde eis aan de subsidiëring van het project gekoppeld is, is dit wel denkbaar. Voor de distributeurs, in dit geval Telenet en Interkabel, betekent de MHP-standaard dat distributeurs de omroepen en bedrijven hierdoor technisch niet aan zich konden binden en dat er geen inhoudelijke eisen gesteld konden worden. Doordat de overheid het gebruik van мн P-standaard als voorwaarde stelde, werkte ze niet alleen een groeiende macht van de kabeldistributeurs tegen, maar voldeed zij bovendien aan Europese aanbevelingen ten gunste van MHP als standaard voor set-topboxen. ${ }^{\text {I }}$

\section{Positieve gebruikerservaringen}

De toepassingen die door Telenet, de Vlaamse overheid, de omroepen en commerciële partijen zijn aangeboden, werden door Vlaamse testgebruikers positiever ontvangen dan het interactieve televisieaanbod in Nederland. Uit een eindrapport van Telenet blijkt dat testgebruikers goed op de hoogte waren van de mogelijkheden van interactieve programma's. Die programma's werden duidelijk bevonden in de 'manier van deelnemen'.52 Ook werd interactiviteit van reeds populaire programma's hoger gewaardeerd dan van minder populaire programma's. Het inzetten van een klein aantal goed bekeken programma's als DOE DE STEMTEST, PEKING EXPRESS, EXPEDITIE ROBINSON en IDOol bleek dus een goede keuze. Van de interactieve diensten 
waardeerden testgebruikers de elektronische programmagids, de televisieprogramma's on-demand en de mogelijkheid om te e-mailen het meest. Ook werden deze diensten het meest gebruikt: iets meer dan de helft van de gebruikers raadpleegde dagelijks de elektronische programmagids, ongeveer eenderde gebruikte de communicatiedienst (inclusief e-mail) en eenvijfde keek dagelijks televisie 'op aanvraag'. De e-mail applicatie werd, zoals verwacht, met name actief gebruikt door kijkers die geen internetverbinding hadden. In huishoudens mét een internetverbinding werden vooral alleen nieuwe e-mails gelezen. De webomgevingen van bedrijven en de overheid werden aanmerkelijk minder vaak gebruikt. Dit betekent niet per se dat er sprake was van een gebrek aan interesse. De toepassingen van bedrijven waren nauwelijks veranderlijk en vroegen dus niet om herhaaldelijk bezoek. Ook overheidsinformatie behoeft een gebruiker niet dagelijks te raadplegen, maar wordt opgezocht wanneer er een concrete aanleiding voor is. Volgens een intern eindrapport van Telenet bleef interactieve digitale televisie (iDTv) daarom een welkome aanvulling op het internet:

'Concluderend kunnen we zeggen dat iDTv een positief adoptiepotentieel heeft, waarbij TV op maat (programma's en films op aanvraag, themakanalen, ...) en eenvoudig opnemen de belangrijkste troeven zullen zijn om digitale televisie tot een succes te maken. Het is eveneens duidelijk dat iDTv via een lagere drempel Vlamingen, die dit momenteel niet kunnen, toegang zal kunnen bieden tot een aantal belangrijke informatiebronnen en egovernmentdiensten waardoor de digitale kloof zal verkleinen. ${ }^{53}$

Eind 2006, enkele maanden na de succesvolle afronding van het project, volgde de commerciële lancering van interactieve digitale televisie door Telenet. Naast de 300 testgebruikers konden nu alle Vlamingen interactieve televisieabonnementen afsluiten. Als antwoord op deze lancering kwam ook telecomaanbieder Belgacom met eigen aanbod van 'interactieve' diensten. Anno 2008 typeren de toepassingen die tijdens Vlaanderen Interactief zijn ontwikkeld nog steeds de gebruiksmogelijkheden van de digitale televisieabonnementen die Telenet aan huishoudens biedt. 54

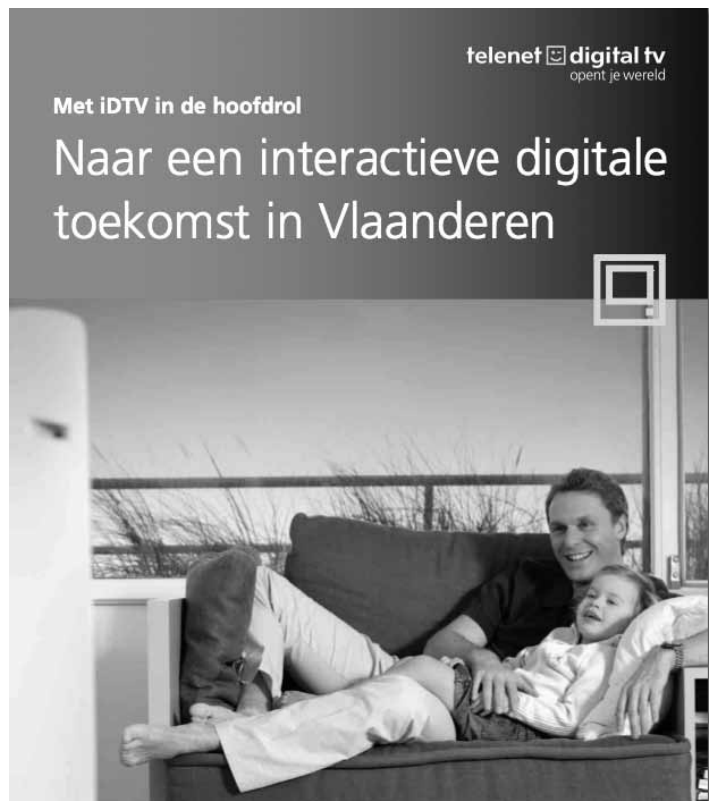

Folder t.b.v. commerciële uitrol iDTV, 2005.

Bron: Telenet communicatiedienst, Naar een interactieve digitale toekomst in Vlaanderen, Mechelen, Telenet NV 2005 (8-1-o6 geraadpleegd) 


\section{Interactieve televisie als institutioneel compromis}

Bovenstaande analyses tonen aan dat de ontwikkeling van digitale interactieve televisie in zowel Nederland als Vlaanderen door instituten niet zozeer gezien werd als een nieuwe vrijblijvende mogelijkheid als gevolg van digitalisering, maar als een noodzakelijke stap om zich in de toekomst te handhaven. Terwijl de kabeldistributeurs als doel hadden om nieuwe winsten te creëren in een verzadigde markt, beschouwden de omroepen de digitalisering van televisie als een onvermijdelijke verandering waar zij, door het ontwikkelen van nieuwe interactieve diensten, maar beter op voorbereid konden zijn. De plannen van deze partijen kunnen in die context dus ook gezien worden als een extensie van de bestaande institutionele doelen: omroepen gaven bestaande programma's een interactieve dimensie, distributeurs breidden hun abonnementen uit met nieuwe diensten en in Vlaanderen gebruikte de overheid de televisie als alternatieve informatievoorziening naast het internet. Het proces van ontwikkeling werd echter niet alleen beïnvloed door een constellatie van motieven, maar ook door technische, economische, culturele, bedrijfsorganisatorische en politieke omstandigheden. Met name de verschillen in politieke sturing hebben de interactieve toepassingen en het maatschappelijke succes van interactieve televisie in Nederland en Vlaanderen bepaald. In Vlaanderen hebben - doordat de (tevens hogere) overheidssubsidie direct gekoppeld werd aan de eigen bijdragen voor de pilot - de grote gevestigde partijen zich gelijktijdig ingezet voor de ontwikkeling van interactieve televisie. In Nederland was deze sturing vanuit de overheid en ook binnen de gefragmenteerde Npo afwezig.55 Deze afwezigheid leidde ertoe dat Mediakabel de standaard voor de set-topbox al had bepaald, dat het aanbod van de N Po onduidelijk bleef en dat de samenwerking tussen de omroepen en Mediakabel slechts voor de duur van het project standhield. Door de keuzen die er in het recente verleden zijn gemaakt, bestaan er anno 2008 niet alleen verschillen in het interactieve televisieaanbod, maar ook in het publieke discours. In Vlaanderen heeft het begrip 'interactieve televisie' een bredere betekenis waaronder terugzien van gemiste programma's, interactieve live programma's en verschillende diensten vallen. In Nederland denkt de kijker vooral aan een elektronische programmagids en maar soms aan het kunnen terugzien van gemiste uitzendingen.

Het verschil in begripsvorming en interpretatie van interactieve televisie in Nederland en Vlaanderen - dat voortkomt uit de uiteenlopende ontwikkeling van interactieve televisie in beide landen - toont aan dat de beslissingen van betrokken instituten - en de invloed van tijdelijke, non-technologische contexten op deze beslissingen - nauwkeurig moeten worden bestudeerd, wil men processen van technologische innovatie en de transformatie van media beter begrijpen. Tegelijkertijd geeft deze analyse aan dat de keuze van een overheid, om niet sturend op te treden, fundamentele gevolgen kan hebben voor de concrete ontwikkelingen op het gebied van de media..$^{6}$ 
I De traditionele televisieketen bestaat uit producenten, omroepen en distributeurs. Deze keten gaat uit van televisie als one-way commmunicatiemiddel van deze instituten naar eindgebruikers via broadcasting.

2 De Actor-Network benadering komt voort uit werken van o.a. Michel Callon, 'The sociology of an actor-network: The case of the electric vehicle', in: M. Callon, J. Law \& A. Rip (eds), Mapping the dynamics of science and technology, London I986, p. 19-34; Bruno Latour, 'The powers of association. Power, action and belief. A new sociology of knowledge?', in: J. Law (ed.), Sociological Review monograph 32, London I986, p. 264-280; en John Law, 'Notes on the theory of the actor-network: Ordering, strategy and heterogeneity.', Systems Practice, 5 (4), I992, p. 379-393.

3 Het wetenschappelijke debat over interactieve televisie als normatief begrip heeft allesbehalve een eenduidige definitie opgeleverd; zie bijv. Sheizaf Rafaeli, 'Interactivity: from new media to communication', Sage annual review of communication research: Advancing communication science, I6, London I988, p. IIO-I34; en Jens F. Jensen, 'Interactivity, tracking a new concept in media and communication studies', in: P. Mayer (red.), Computer, media and communication, Oxford I999, p. I60-I87. Ook wordt de vraag gesteld in hoeverre echte interactiviteit überhaupt mogelijk is in de context van gevestigde televisieorganisaties; zie bijv. Pyungho Kim \& Harmeet Sawhney, 'A machine-like new medium: Theoretical examination of interactive TV', in: Media, Culture and Society, vol. 24, 2002, nr. 2, p. 2I7-233; Mark Andrejevic, 'The work of being watched: Interactive media and the exploitation of self-disclosure'. Critical studies in media communication, I9 (2), 2002, p. 230-248; en Daniel Palmer, The paradox of user control, Melbourne DAC, 2003.

4 Brian Winston, Media technology and society - a history: From the telegraph to the internet, London I998; William Boddy, 'Redefining the home screen: technological convergence as trauma and business plan'. In: David Thornborn \& Henry Jenkins (red.), Rethinking media change: the aesthetics of transition, Cambridge 2003.

5 F. van der Ploeg, 'Publieke omroep en nieuwe media. Brief aan de voorzitter van de Tweede Kamer der Staten-Generaal', Den Haag, I2 juli 200I; F. van der Ploeg, 'Nieuwe diensten publieke omroep. Brief aan de voorzitter van de Tweede Kamer der Staten-Generaal', Den Haag, 2I november 2001 .

6 Idem.

7 Idem.

8 E. Brinkman, 'Expertmeeting interactieve televisie; innovatie in de digitale publieke omroep', (verslag) 30 januari 2002.

9 Idem.

Io Van der Ploeg, 'Nieuwe diensten publieke omroep'.

II Brinkman, 'Expertmeeting', 2002.

I2 Nos, 'Projectbeschrijving Nederland-i. DTA/oo-277a', Hilversum, 2I november 2000.

I3 Idem, p.7.

I4 Idem.

I5 Idem.

I6 Gesprek met Hans Bakhuizen, senior beleidsadviseur technologie Publieke Omroep, Hilversum, mei 2005 .

I7 Harry van Vliet, Next generation television, Enschede 200 I.

I8 Informatie over de ontwikkelde programma's en diensten komt voort uit verschillende bronnen: R. van de Paverd, 'itv-dossier' (CD-Rom). Hilversum, juli 2002; Cilia Krüs, 'Interactieve tv; zomer 2002'. Hilversum, 2002; Mr. Zap. URL: http://www.mr.zap.nl (laatst geraadpleegd I augustus 2005); NCRV - Natuur - Walking With Beasts, U RL: http://cgi.ncrv.nl/ncrv/walkingwithbeasts/itv.shtml (laatst geraadpleegd 24 oktober 2005); Nов - 'AVRO's Duivelse Dilemma's', URL: http://www.ondertitel.nl/index.cfm?cfid=40039998\&cftoken=97986592\&ln=nl\&mc=5\&fuseaction=showcases.detail\&ccat=iTV\&sce_id=5 (laatst geraadpleegd I4 december 2005); Nwo - de quiz van 200I, URL: http://www.nwo.nl/nwohome.nsf/pages/NWOP_5VGK8X (laatst geraadpleegd 20 november 2005); Radio.nl, 'NCRV lanceert interactieve versie van zo VADER, zo zooN, 9 novem- 
ber 2000, URL: http://www.radio.nl/2003/home/medianieuws/oro.archief/2000/II/72608.html (laatst geraadpleegd 24 oktober 2005); Tv Home Gebruikerspagina - Geschiedenis - Verdwenen diensten. U RL: http://home.planet.nl/ beren267/geschiedenis/diensten.html (laatst geraadpleegd 29 december 2005); Stoneroos / NCRV. 'Interactieve Demo Stand.nl', 2002, URL: http://www.stoneroos.nl/download/standnl-2002.wmv (laatst geraadpleegd 24 oktober 2005).

I9 Holger Braun-Thürmann, Innovation, Bielefeld 2005

20 Susanne K. Schmidt \& Raymund Werle, Coordinating technology: Studies in the international standardization of telecommunications. Cambridge 1998.

2I Gesprek met Erik Huizer, directeur innovatie en business development Nов Cross Media Facilities, Utrecht, mei 2005.

22 Gesprek met Annelies Kaptein, voormalig manager Marketing \& Communicatie / Nieuwe media NCRV, Hilversum, juli 2005.

23 Cilia Krüs, 'Interactieve tv; zomer 2002'. Hilversum 2002.

24 Idem.

25 Idem.

26 Gesprek met Erik Huizer, 2005

27 R.J.L. van Buren, Keep it simple, keep it relevant. Interactieve televisie in Nederland aan het begin van de 21e eeuw. Doctoraalscriptie Universiteit Twente, 2003; interview met Annelies Kaptein.

28 Idem.

29 'Essent investeert niet meer in kabel', De Telegraaf, 22 september 200 I.

30 Expergroep Digitale Televisie, 'Monitor digitale televisie in Nederland september 2007', Hilversum, 2007, URL: http://www.immovator.nl/files/images/070928\%20Monitor\%20Digitale \%20TV\%20in\%20Nederland\%20sept\%2007.pdf (laatst geraadpleegd 5 augustus 2008).

3I Telenet is een geprivatiseerd bedrijf, maar makt nog wel voor $43 \%$ gebruik van het overheidsnetwerk. Interkabel is geheel in handen van de Vlaamse overheid en bestaat uit de bedrijven Integran, wVEM, PBE en Interelectra.

32 Gesprek met Peter Suetens, netmanager e-vRT, en Sven Rousseaux, iDTv Knowledge Center, Vlaamse Radio en Televisieomroep, Brussel, september 2005.

33 Gesprek met Koen Heylen, Telenet, Mechelen, september 2005; Ministerie van de Vlaamse Gemeenschap, 'Persmededeling van de Vlaamse regering vergadering van I8 juni 2003; Interactieve televisie eind 2004 in Vlaanderen', Brussel 2003.

34 Dirk van Mechelen, 'Slottoespraak van Dirk van Mechelen, Vlaams minister van Financiën en Begroting, ruimtelijke Ordening, Wetenschappen en Technologische Innovatie'. Gepresenteerd op het congres 'Interactieve Digitale Televisie in Vlaanderen', Brussel I2 februari 2004. - Interview met Koen Heylen, Telenet, september 2005.

35 Telenet N.v, 'Naar een interactieve digitale toekomst in Vlaanderen'. Mechelen 2005.

36 Idem; Persmededeling van het kabinet van minister Patricia Ceysens, Vlaams minister van Economie, Buitenlands Beleid, en e-Government, 7 juni 2004. Brussel 2004.

37 Van Mechelen, Slottoespraak.

38 Idem.

39 VRT, 'Digitaal Thuisplatform; Eindrapport'. Brussel 2003.

40 Idem.

4I Gesprek met Peter Suetens en Sven Rousseaux.

42 M. van Keulen, 'Beleidsbrief Media 2004. Vlaams ministerie van Media, Wonen en Sport.' Brussel 2003.

43 Instituut voor aanmoediging van innovatie door Wetenschap en Technologie (IWT), 'Eindrapport Vlaanderen Interactief. Proefproject interactieve digitale televisie in Vlaanderen', januari 2005 .

44 Citaat Jozelf Mertens in: R. Cockx, 'De Salonrevolutie', 6 december 200I. URL: http://www. trends.be/CMArticles/ShowArticle479.asp?articleID=27740\&sectionID=235 (laatst geraadpleegd 20 november 2005).

45 'Interkabel wil hap uit koek digitale Tv', De Tijd, 30 augustus 2004, p. 5. 
46 Deze bedrijven waren Neckermann, de Gouden Gids, Electrabel, Easy Immo, Extrafilm (je foto's op tv bekijken), Nationale Loterij, Vlaamse Automobilistenbond, Xquiz, Stella Artois, Libelle, Humo, Reiswijzernet, Weerıd, Dexia en Cash.

47 Informatie over de ontwikkelde programma's en diensten komt voort uit verschillende bronnen: Telenet. Promotiefilm Telenet idTv, 2004, URL: www.vlaandereninteractief.be/filmpje.html (laatst geraadpleegd Io januari 2005); vTM, Promotiefilm vTM interactief, 2005, URL: http://www. vtm.be/asx/idtv/idtvletterbox.asx (laatst geraadpleegd 8 januari 2006); vRT 'Promotiefilm Vlaanderen Interactief', 2005, u RL: http://www.vrt.be/vrt_master/over/vrt_overvrt_innovatie_otw_vlinteract_video/Vl_Interactief-o05IOIO-I04638-HB.wmv (laatst geraadpleegd 8 januari 2006); R. Verhelst, 'Presentatie Telenet. Ge jaarcongres Tv en Internet', Amsterdam, 25 november 2004; Telenet EPGweb, URL: http://www.telenet.be/sites/epgweb/ (laatst geraadpleegd 8 januari 2006); Website Vlaamse Infolijn, U RL: http://www.vlaamseinfolijn.be/ (laatst geraadpleegd 3I oktober 2005); Website Vlaanderen Interactief, URL: http://www.vlaandereninteractief.be (laatst geraadpleegd 23 oktober 2004); Website RadioVisie, 'Het "Idool 2004" wordt ook interactief verkozen', Io december 2004, URL: http://www.fmradio.be/new/nieuws.php?id=21216 (laatst geraadpleegd 20 november 2005); Safe. <http://www.vtm.be/tv/index_programma_safe.htm> (laatst geraadpleegd 20 november); sBsBelgium - vT4. <http://www.vt4.be>, (laatst geraadpleegd 20 november 2005).

48 B. Souffeau, 'Eerste IDTV Congres in Vlaanderen', I3 februari 2004. URL: http://www.internetjournalistiek.be/weblog/weblog_detail.php?nieuwsid=207 (laatst geraadpleegd 29 december 2005); gesprek met Peter Suetens en Sven Rousseaux.

49 Peter Suetens in: R. Cockx, 'De Salonrevolutie'.

50 Ministerie van de Vlaamse Gemeenschap, 'Persmededeling van de Vlaamse regering vergadering van I8 juni 2003; Interactieve televisie eind 2004 in Vlaanderen'.

5I Communications Committee, Directorate-General Information Society, European Commission, 'Working Document on the implementation of standards and interoperability of digital interactive television under the new regulatory framework, Brussel, 2 december 2002.

52 IWT, Eindrapport Vlaanderen Interactief, januari 2005. De auteur heeft inzage gekregen in het 'Eindrapport Vlaanderen Interactief' maar kan geen exacte percentages weergeven vanwege de vertrouwlijkheid van dat rapport.

53 Idem, p. 84.

54 BrochureTelenetDigitaleTelevisie. uRL:http://telenet.be/media/fs/I/others/pdf/brochures/ Broch_iDTV_Co8_TELESALES_NL_VL.pdf (laatst geraadpleegd 5 augustus 2008).

55 Omdat het niet duidelijk is welk bedrag er nu precies door de N PO en de Vlaamse instituten aan de pilots is besteed, is een directe financiële vergelijking helaas niet mogelijk.

56 Een uitgebreide analyse van dit onderzoek is in 2006 online gepubliceerd als doctoraalscriptie: 'Achter de Schermen van itv', en is te vinden op: http://igitur-archive.library.uu.nl/student-theses/2006-0324 83025/Doctoraalscriptie_E_Baaren_Achter_de_Schermen_van_iTV.pdf. Voor hun medewerking en hulp dankt de auteur Hans Bakhuizen, Erik Huizer, Annelies Kaptein, Koen Heylen, Peter Suetens, Sven Rousseaux en Eggo Müller. 